\title{
To Assess the Influence of Policy and Legal Framework On ICT Innovation
}

\author{
Collins Ochieng Ochola and Prof.Wausi Agnes Nduku \\ School of Computing \& Informatics, University of Nairobi
}

\begin{abstract}
A study to assess the influence of policy and legal framework on Information Communication Technology (ICT) innovations in Kenya. The objective was to analyze the legal factors affecting the innovation of ICT products in Kenya with a focus was on Government regulations, Policy and Industry related factors, Copyright Infringement and Enforcement regime. Purposive sampling was used for the study while the instrument for data collection was structured questionnaires. The findings are Competition amongst major industry players' influences innovation as every player wants to have a competitive advantage of other market players. Additionally, the government plays a key role in innovation through laying rules and regulation that govern industry players. Issuance of license to industry players this sets the terms of reference between the government and the entities. In view of the findings, Government regulation of ICT sector is of uttermost importance it protects the rights of players in the market, the environment as well as hold the players accountable. Forces of demand and supply regulate the available market for the innovations as innovators have the same target market hence how they position their items enable them get clients.
\end{abstract}

\section{Background of the Study}

Software innovation is defined as the systematic application of technological and scientific knowledge, methods, and experience in the design, testing, implementation and documentation of software (Laplante, 2007). In the past few decades, the world has witnessed fundamental shifts in the manner in which software's are developed and deployed. Before this development in software engineering there existed relatively few software systems which were custom built and ran on a limited number of frequently disconnected computers (Apiwattanapong \& Harrold, 2002).

\section{Literature Review}

\section{General Equilibrium Theory}

Leon Walras developed this Theory in his work Elements of Pure Economics ( Walras, 1957). This theory attempts to explain the behavior of demand, supply, and prices in a whole economy with several or many cooperating markets, by seeking to prove that a set of prices subsists that will result in an overall equilibrium.

\section{Empirical Review}

Methodology

Population in statistics is the specific population about which information is desired. According to Field (2014), a population is a well-defined or set of people, services, elements, events and group of things or households that are being investigated. Nachmias and Nachmias (1990) contend that studies can subjectively pick the samples who will contribute to the study based on the competence, knowledge and expertise. This 
was the rationale for purposive sampling a sample of 75 respondents was chosen based on years of experience. The questionnaires were delivered through drop and pick method, the research assistants hand delivered the questionnaires to the respondents.

According to Mugenda and Mugenda (2013), validity is the accuracy and meaningfulness of inferences, which are based on the research results. To enhance construct and content validity, the lecturers in the field of Information Technology first appraised the research instruments. Reliability is a measure of the degree to which a research instrument yields consistent results or data after repeated trials (Mugenda and Mugenda, 2013. The researcher ensured use the internal consistency techniques Cronbach's alpha to test for reliability. The study adopted use of multiple linear regression models. The model predicts the extent to which each of the four independent variables are related.

\section{Findings}

\section{Legal Factors affecting the innovation of Software Developers in Kenya}

Majority of the respondents agreed that innovators are influenced by what is available in the market with slight modification and improvement. It was also noted that respondents agreed that the cost of training ICT innovators moderately influenced innovation.

The finding are in line with Crespi and Pianta (2006) who established that innovation enhances productivity growth thereby affecting demand and supply as end users prefer items that offer competitive advantage. Nesta (2010) corroborates the findings that consumers prefer new ideas that are readily available and affordable. Hence innovators respondent directly to consumer needs, they also take into account production the cost of production and selling price. OECD (1996c) confirms competition in the market encourages research and innovation hence new ideas in the market.

\section{ICT Regulations}

Majority of the respondents agreed that the government is a key stakeholder in regulation of ICT innovation this was demonstrated by a mean of 4.75. The government has the power to issue licenses to firms to engage in economic activities. Most of the respondents agreed to a great extent that the government regulates and promote the ICT industry through tax holidays to encourage innovators and promote growth in ICT industry.

The findings corroborates OECD (1996c) that states regulation has various effect on innovation: on the economic sphere it encourages competition and openness, while on social sphere it creates technical demands for industries acting as focal point a round which they focus their work. Kahn et.al (1999) ascertains that incentive based regulation tend to aid market and social innovation as firms ride on the leeway to maximize on the commercially viable options offered.

\section{ICT Innovation Policies}

All software's have terms and conditions that users are expected to adhere to before use, the terms and conditions follow prescribed software safety-related policies and regulations. Most respondents agreed to a greater extent that innovators work within policies and regulations to develop software to minimize legal challenges resulting from failures of software. In addition, most software companies have internal policies, procedures and regulations that govern innovation. This is aided by training and capacity building of staff to 
develop ICT products which are unique and innovative. The findings are in tandem with Davis (2006), who ascertained that patents and copyrights give firms exclusive right to earn incentive from their invention. Landes and Posner (1987) contend that patents stimulate firms to invest in research and development as it gives them exclusive right to earn rents from the innovation.

\section{Techniques for Mitigating Legal Liability}

Majority of the respondents agreed that innovators do software analysis that is conducting hazard analysis of threat posed to health, property and environment. In addition, the innovators assess how a system can fail and how best to reduce the risk so as to minimize risks the software can cause, as the mean was 4.55. The standard deviation for the response was small indicating the data is normally distributed around the mean.

The innovators seek a second opinion from third parties who were not involved in the development the software so as to create room for critic and improvements. Hence most respondents agreed that third party testing enhances second opinion on the software, as the mean was 4.62. The software's are formally verified in case they meet some requirement before being launched into the market. Most respondents agreed with the statement to a greater extent, as the mean was 4.67.

Code review and software testing enable innovators to collaborate to determine faults hence reducing the impact of mitigation. While architectural design review and debugging by external vendor help to identify faults and trace liabilities and omissions which may affect the quality of innovation.

\section{Regression Results}

Table 4.6 Model Summary

\begin{tabular}{ccccc}
\hline $\mathrm{R}$ & R Square & $\begin{array}{c}\text { Adjusted R } \\
\text { Square }\end{array}$ & $\begin{array}{c}\text { Std. Error of the } \\
\text { Estimate }\end{array}$ & Sig. \\
\hline $.7879^{\mathrm{a}}$ & .7802 & .7709 & 40.3056836 & 0.010 \\
\hline
\end{tabular}

From the table 4.6 above, there is a significant relationship between the dependent and independent variable as the $\mathrm{P}$-value is less than 0.05 significance level. In addition the $\mathrm{R}$ value is 0.7879 indicating that there is a positive relationship between independent and dependent variable. While $\mathrm{R}$ is 0.7802 indicating that the independent variable explains $78.02 \%$ change on the dependent variable.

Table 4.7: ANOVA Table

\begin{tabular}{|c|c|c|c|c|c|}
\hline & Sum of Squares & Df & $\begin{array}{c}\text { Mean } \\
\text { Square }\end{array}$ & F & Sig. \\
\hline Regression & 26466.215 & 4 & 6616.554 & 4.073 & $0.021^{\mathrm{a}}$ \\
\hline Residual & 22743.674 & 70 & 1624.548 & & \\
\hline Total & 49209.889 & 74 & & & \\
\hline
\end{tabular}

Predictors: (Constant), ICT Regulations, ICT innovation Policies, Economic Factors 
Dependent Variable: Innovation of ICT Products

\section{Test of Hypothesis Using ANOVA}

F-calculated (4.073) is greater than F-critical (0.021)

Conclusion: We reject Null hypothesis, hence legal systems have an influence the innovation of ICT products in Kenya.

\section{Regression Coefficients}

\begin{tabular}{|c|c|c|c|c|c|}
\hline & \multicolumn{2}{|c|}{$\begin{array}{l}\text { Unstandardized } \\
\text { Coefficients }\end{array}$} & \multirow{2}{*}{$\begin{array}{l}\text { Standardize } \\
\text { d } \\
\text { Coefficients } \\
\text { Beta }\end{array}$} & \multirow[t]{2}{*}{$\mathrm{T}$} & \multirow[t]{2}{*}{ Sig. } \\
\hline & B & $\begin{array}{l}\text { Std. } \\
\text { Error }\end{array}$ & & & \\
\hline (Constant) & .041 & .258 & & .930 & .000 \\
\hline ICT Regulations & .494 & .077 & .297 & 3.798 & .002 \\
\hline Economic Factors & .430 & .070 & .188 & 3.290 & .001 \\
\hline ICT Innovation Policies & .413 & .062 & .013 & .215 & .001 \\
\hline
\end{tabular}

a. Predictors: (Constant), ICT Regulations, ICT innovation Policies, Economic Factors

b. Dependent Variable: Innovation of ICT Products

The established multiple linear regression equation is:

$\mathrm{Y}=0.041+0.494 \mathrm{X}_{1}+0.430 \mathrm{X}_{2}+0.413 \mathrm{X}_{3}$

From the regression model above, every unit change on ICT regulation there is 0.494 unit change on ICT products, all other factors held constant. While every unit of change on economic factors there is 0.430 unit change on ICT products all other factors held constant. While for every unit change in ICT innovation policy, there is 0.413 unit change in ICT products. From table 4.8 above ICT regulation, economic factors and ICT innovation policies influence innovation of ICT products as p-values were less than 0.05 significance level.

Table 4.9: Correlation of the Variables

\begin{tabular}{|l|l|l|l|l|}
\hline Correlations & & $\begin{array}{l}\text { ICT } \\
\text { Regulations }\end{array}$ & $\begin{array}{l}\text { ICT Innovation } \\
\text { Policies }\end{array}$ & Economic Factors \\
\hline $\begin{array}{l}\text { ICT } \\
\text { Regulations }\end{array}$ & Pearson Correlation & & $.657 * *$ & $.704 * *$ \\
\hline
\end{tabular}




\begin{tabular}{|c|c|c|c|c|}
\hline & Sig. (2-tailed) & .030 & .310 & .230 \\
\hline \multirow{2}{*}{$\begin{array}{l}\text { ICT } \\
\text { Innovation } \\
\text { policies }\end{array}$} & Pearson Correlation & $.657 * *$ & 1 & $.241 * *$ \\
\hline & Sig. (2-tailed) & .030 & .400 & .000 \\
\hline \multirow{2}{*}{$\begin{array}{l}\text { Economic } \\
\text { Factors }\end{array}$} & Pearson Correlation & $.530 *$ & $.289 * *$ & 1 \\
\hline & Sig. (2-tailed) & .130 & .130 & .240 \\
\hline
\end{tabular}

** Correlation is significant at the 0.01 level (2-tailed).

* Correlation is significant at the 0.05 level (2-tailed).

The correlation results presented on Table 4.9 shows positive linear association between ICT regulations and ICT innovation. A high positive linear association was established between ICT policy and economic factors, the results imply there is a strong correlation between the variables under study

\section{References}

[1] Apiwattanapong, T., \& Harrold, M. J. (2002). Selective path profiling. In Proc. of the ACM Workshop on Program Analysis for Software Tools and Engineering, 35-42.

[2] Bainbridge,T.H., (2013). Software patents and the metaphysics of section 271(f). Commun. ACM, 50(6):15-19,

[3] Baker, L. (2010). Needed: An ethical code for library administrators. Journal of Library Administration, 1-17

[4] Freibrun, E. (2010). Intellectual Property Rights in Software: What They Are and How the Law Protects Them. Retrieved 2 11, 2016, from Freiburg: http://www.freibrun.com/articles/articl2.htm

[5] Gallini, N. (2010). Patent Policy and Costly Imitation. RAND Journal of Economics, 52-63.

[6] Mugenda, O., \& Mugenda, A. (2013). Research Methods: Qualitative and Quantitative Approaches. Nairobi. Africa Center for Technology Studies.

[7] Yousef. (1987). Restatement (Third) Of Foreign Relations Law Of The United State. Treatise or commentary, 89-110. 